\title{
Influence of the Bologna Process on African higher education: Ethiopian higher education in focus
}

Gebremeskel, Haftu Hindeya $\bowtie$

Graduate Student, School of Management, University of Tampere, Finland (haftu_hg@yahoo.com)

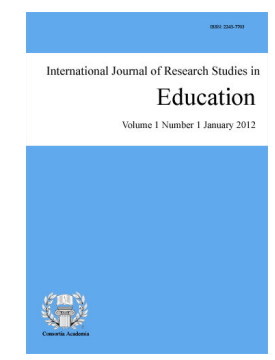

ISSN: 2243-7703 Online ISSN: 2243-7711

OPEN ACCESS

\section{Abstract}

Taking the Ethiopian public higher education as a case in point, this paper examined the influence of the Bologna Process on African higher education. It showed how the goals of the Process have been reflected on the current reforms undergoing in Ethiopian higher education. In doing so, relevant policy documents and national guidelines were reviewed taking the Bologna elements as a framework for discussion. Developments of partnership between the African and European Unions in higher education were also examined to see the influence of the Process at continental level in the foreseeable future. Though the process might have influence in other aspects of Ethiopian higher education, emphasis was given in this paper to elements reflected in academic curricula and teaching learning process. In this regard, elements such as modularization, European Credit Transfer and Accumulation System (ECTS), Competence Based Education (CBE), flexibility of learning and recognition of prior learning were identified. Opportunities and challenges of implementing the spillover effects of the Process were also discussed.

Keywords: ECTS; competence based education; modularization; prior learning; flexibility of learning path 


\section{Influence of the Bologna Process on African higher education: Ethiopian higher education in focus}

\section{Introduction}

Contemporary developments around the world have brought about increasingly challenging times for higher education. Higher education (HE) is becoming challenged by the pressures of massification, increasing forms of accountability and competition, new stakeholder expectations, and rapidly changing environment (Taylor, Hanlon \& Yorke, 2013). The emergence of new technologies, internationalization of HE expressed as "the process of integrating an international, intercultural or global dimension into the purpose, functions or delivery of post-secondary education (Knight, 2003, p. 2), and globalization in general have facilitated this dynamics. The globalization of the world economy also influenced HE globally to engage in in-depth reforms to meet the new economic challenges (Sewonu, 2010). Particularly, the exchange of ideas and knowledge among higher education institutions (HEIs) and others who have interests in HE has increased; mainly attributed to increase in interaction and need for collaboration. In addition, access to ICT in developing countries has facilitated interaction and use of knowledge developed somewhere. In this regard, it is common to observe these days that countries and universities are benchmarking and exchanging new ideas. This general move towards sharing ideas and getting the best out of the practice on one hand and move towards the convergence on the other hand are getting support from governmental and non-governmental institutions. For instance, the move to support HE reform efforts by mega institutions such as the European Union, World Bank and other similar institutions has facilitated this convergence that in turn led to close link among HEIs in the world. In this regard, it is worth mentioning the EU which is supporting the endeavor of HEIs to establish a European Higher Education Area as an effort to unify Europe. The EU has been keen to support European HE in facilitating their reform efforts. In addition, the shift of the World Bank in its position to support HE in developing countries, the attempt of the AU to harmonize African HE and OECD's move towards encompassing HE issues into its economic and political objectives could be taken as evidence of such moves.

Another important development seen in the last two decades is the enhanced involvement of governments in HE. A good example for this is the Bologna Process, where ministers agreed to create HE area in Europe (EUA, 2010). The Bologna Process since then has shown significant development in terms of scope of influence on and shaping of HEIs in Europe and other parts of the world. In this regard, it has played a major role in transforming European HE. For instance, it has made significant changes that have enabled the European Higher Education Area to emerge in member countries and laid the ground for HE to serve an increasing range of societal demands. During this process, HE structures have been modified, quality assurance systems developed, mechanisms to facilitate mobility established, and a range of issues for the social dimension of HE identified (Education, Audiovisual and Culture Executive Agency, 2012).

In this paper, attempt was made to show the spillover effects of the Bologna Process outside the European Higher Education Area. Particular focus was given to see how the Process has influenced African HE taking the case of Ethiopia. The paper was separated into four sections. The sections include Bologna Process: an overview, African HE and Bologna Process, influence of Bologna Process on Ethiopian HE, and the opportunities and challenges observed. The first section elaborates how Bologna came into effect. The goals of the Process were reviewed and taken as a framework for discussion. Doing so is essential because it is based on these goals of the Process that one could see how they are reflected in other countries. The second section of the paper is a glance at the general picture of African HE. Here attempt was made to see the current developments of African HE taking Bologna Process as a basis for reflection. The third section shows how Ethiopian HE is influenced and being influenced by the Process. In this section, practices of the current reforms made in Ethiopian HEIs were reviewed. Selected elements of the Process were seen vis-à-vis the practices. The last section, opportunities and 
Influence of the Bologna Process on African higher education: Ethiopian higher education in focus

challenges, portrayed the opportunities that Ethiopian HE has got and the challenges facing in its attempt to implement the elements of the Process. In this paper, it should be noted that discussion of the Process throughout was made to see to what extent the selected elements have been reflected in Ethiopian HE using relevant literature. In fact, caution should be taken as some of the elements may be there or appeared with or without the Process.

\subsection{Purpose of the Study}

As mentioned above, recent developments in HE have heightened the need for reform. As part of this reform process, many countries worldwide are adapting the elements of the Bologna Process that has been implemented in Europe. For instance, the Asia Pacific region's Brisbane Communique' initiative is a reflection of its intent to imitate the Bologna Process within the region (Roger \& Chao, 2011). Other countries in Latin and North America have also shown interest to implement the Process. Likewise, African countries are also implementing selected elements of the Bologna Process. So far, however, there has been little discussion about its influence. Initiated by lack of studies, this paper set out to assess how Bologna Process goals have been reflected in Africa taking the case of Ethiopian HE. To do so, relevant policy documents and national guidelines were reviewed taking the Bologna goals as a framework for discussion. All public universities in Ethiopia undergoing reform on their academic programs and teaching learning process were discussed for two reasons. The national guidelines reviewed encompass all public universities in the country, and all public universities have been involved in the reform process. In addition, as the researcher was one of the members of the task force established to provide support to public universities at national level while modularizing and harmonizing their academic programs, he has used his observation of the practices to show how the selected elements of the Process are reflected.

\subsection{Significance of the Study}

The significance of study is mainly to stimulate debate and show how the Bologna Process is influencing HE development in Africa. In this regard, the study may initiate future studies and bring the issue to the attention of researchers as there are limited studies, if not none, that portray how the Process is reflected in Ethiopian and African HEIs in general. In addition, as Bologna's scope of influence is growing (Eg. in Asia, Latin and North America), the study may have relevance to wider audience to show how the Process goals are reflected in HE and indicate the possible challenges and opportunities in implementing it.

\section{Bologna Process: An overview}

The move towards having a common European Higher Education Area (EHEA) was mainly based on the initiative of the Bologna Process in 1999 by the Ministers of Education and university leaders from 29 countries (EUA, 2010). In the Bologna declaration of 1999, European ministers with responsibility for HE initiated the Bologna Process by setting out the goal of establishing the EHEA by 2010. After a decade of reforms, at their Leuven/Louvain-la-Neuve summit in April 2009, ministers reaffirmed their commitment to continue the Bologna Process and expressed the need to consolidate the reforms in the period towards 2020. In the Bologna Declaration, the ministers affirmed their intention to: adopt a system of easily readable and comparable degrees, implement a system based essentially on two main cycles, establish a system of credits (such as ECTS), support the mobility of students, teachers, researchers, and administrative staff, promote European cooperation in quality assurance and promote the European dimensions in $\mathrm{HE}$ (in terms of curricular development and inter-institutional cooperation) (EUA, 2014).

This reform is currently in its heydays encompassing officially 46 countries. The creation of a EHEA has developed into a major reform. According to Sweeney (2010, p. 16), "The Bologna Process is neither a set of rules nor a straitjacket. It is a framework designed to enable effective co-operation on the basis of transparency and mutual recognition." It is possible to say that there was huge political support for Bologna throughout Europe as many academics, politicians and institutions have been engaged to fully implement its ethos and 
Gebremeskel, H. H.

principles.

Since 1998, seven ministerial conferences devoted to mapping out the short- and medium-term goals of the Bologna Process and reviewing progress in implementation have been held in different European cities, namely Paris (at the Sorbonne University), Bologna, Prague, Berlin, Bergen, London, Leuven, and in Bucharest in April 2012. The EHEA was officially launched by the Budapest-Vienna Declaration in May 2010, and a roadmap has been drawn for further progress to be made by 2020. Hence, though the Bologna had the aforementioned objectives when launched; it has got a very wide scope and influence in series meetings. New elements were added and currently its scope has widened from a goal to ten goals, as can be seen in the diagram below.

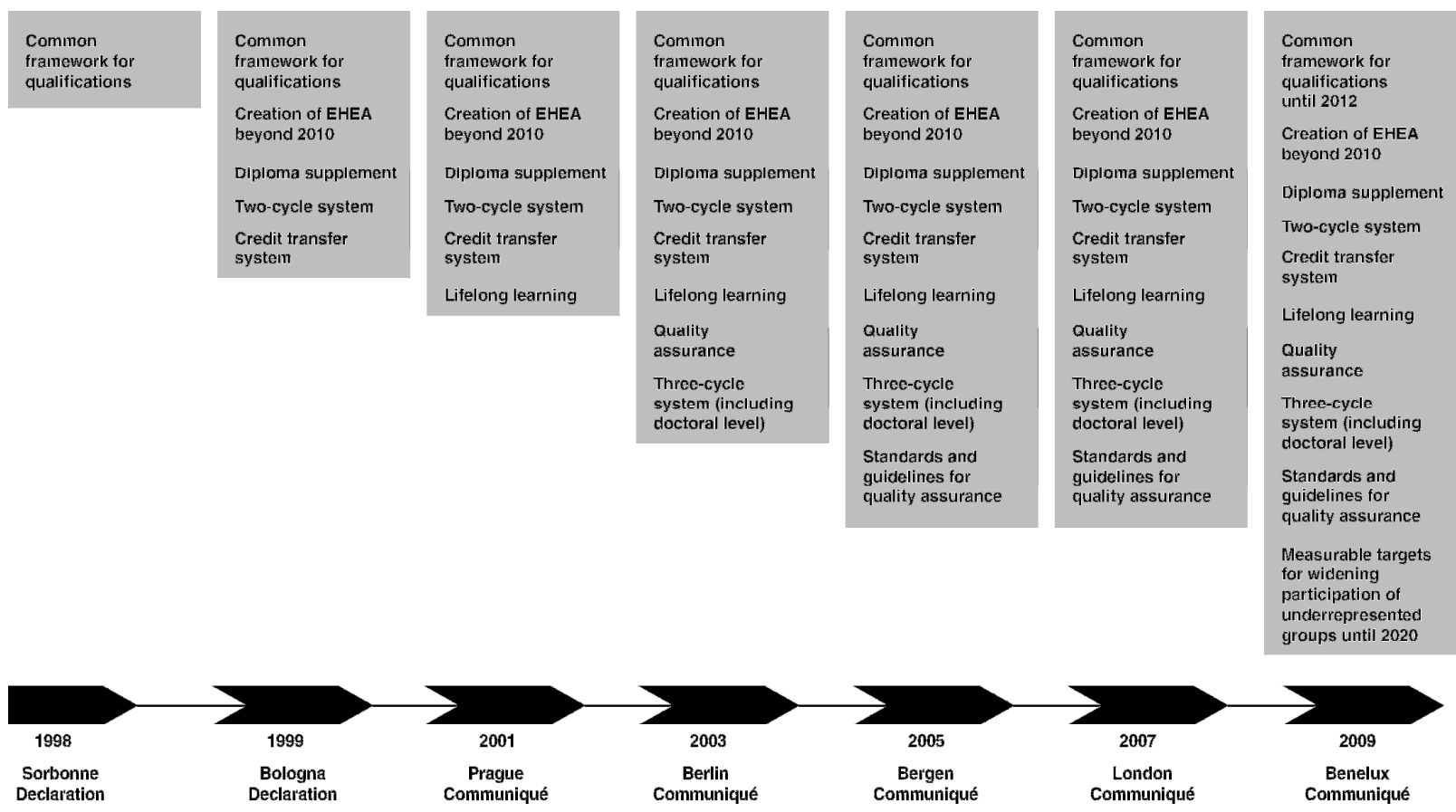

Source: Goals of the Bologna process (Voegtle, Knill, \& Dobbins, 2011, p. 81)

One of the main goals of the Bologna Declaration was 'to ensure that the European HE system acquires a world-wide degree of attraction' (Bologna Follow-up Group, 2009, p.6). However, in most parts of Europe, the international promotion and marketing of $\mathrm{HE}$ is recent phenomenon for it is viewed as a commercial practice, and as such incompatible with academic values, rather than as a natural element of national and European public policy (Bologna Follow-up Group, 2009). Nevertheless, because of emergence of stronger competition internationally among HE providers, together with a strong drive towards internationalization in many countries of the EHEA and a greater importance given to a sufficient share of international students and the benefits gained through the Process, it has got spillover effect in influencing other HE systems worldwide. The influence of Bologna Process on structure and function of HE was asserted by many educators. For instance, according to Karseth (2006), the main drive for moving into the policy of curriculum restructuring on the national and international arena to develop a unified system that facilitates mobility, transparency and recognition of qualification from one educational setting to another was the Bologna Process as it attempted to organize HE within a more coherent and compatible European framework. It also is observable in the reform process that European HE systems are undergoing radical restructuring in line with objectives defined by the Process (Keeling, 2006).

In general, "the Bologna Process can be seen as a concerted pan-European response to these societal shifts; it is a unique process that will continue to shape reality for years to come" (Crosier \& Parveva, 2013, p. 19). Since 1999, the Process has created considerable interest in many parts of the world. In several countries, 
Influence of the Bologna Process on African higher education: Ethiopian higher education in focus

concrete initiatives have been taken to implement some of its features (e.g. in Israel, Kazakhstan, Maghreb countries or lusophone countries in Asia and Africa). Some countries have expressed interest in the exchange of good practice and cooperation on particular issues, such as quality assurance, recognition, exchange of students, or lifelong learning (e.g. Australia or New Zealand) (Bologna Follow-up Group, Report on the EHEA in a global context, 2009, p.12). This influence looks strategic in some cases. For instance, the Communique of the Conference of European Ministers Responsible for HE in its agendum "International openness" clearly put the need to widen the scope of the Bologna Process to the international community. It states:

\begin{abstract}
We call upon European higher education institutions to further internationalize their activities and to engage in global collaboration for sustainable development. The attractiveness and openness of European higher education will be highlighted by joint European actions. Competition on a global scale will be complemented by enhanced policy dialogue and cooperation based on partnership with other regions of the world, in particular through the organization of Bologna Policy Fora, involving a variety of stakeholders (Leuven \& Louvain-la-Neuve, 28-29 April, 2009, p. 4).
\end{abstract}

Hence, seen from these strategies of influence which sometimes are subtle, the quest for looking into its influence in other HE systems appears to be reasonable. To do so, the aforementioned elements of the Process were taken as basis for discussion. Now let us have a glance on how the Bologna Process is reaching out the African higher education.

\title{
3. African Higher Education and the Bologna Process
}

As mentioned above, $\mathrm{HE}$ is now expected to meet a wide range of needs for evolving knowledge societies and economies. Among the missions HE is supposed to meet include: "educating ever-larger numbers of the population, creating new opportunities for non-traditional students, developing research and innovation, responding to local and regional economic challenges, and acting to improve quality and efficiency in all aspects" (Crosier \& Parveva, 2013, p. 19). To address all these demands of $21^{\text {st }}$ century, the African HE system is undergoing tremendous transformation process similar to other HE systems in the world. This transformation of HE system is observed at all levels: national, regional and continental. Similar to other continents, African HEIs are also under the influence of the Bologna Process.

Reforms are under way in almost all countries of the African continent and all universities and HEIs feel compelled to adopt the Bologna Process (Sall \& Ndjaye, 2008). There were some clear signs that the Bologna Process, as an example of good practice in the field of policy development, has entered Africa (Zgaga, 2006). At this point in time, Zgaga made a reference to the AU meeting of experts on revitalization of HE in Africa. One of the important issues discussed at the meeting was the relevance of system approach as opposed to dealing with single institution, organization or even country in higher education. This important view of the need for collective responsibility and mutually supportive action towards the integration agenda of the AU was clear sign of Bologna's influence which ultimately could move towards creating an African HE area alike to Europe. In this regard, considerable efforts have been made to create an African HE space. The African Union's HE harmonization strategy was endorsed by education ministers in 2007. The focus is on three key areas: qualifications recognition, harmonization of systems, and quality assurance. An ambitious goal has been set for 2015, when a continental framework of higher educational qualifications is expected to be in place (MacGregor, 2011).

Side Event of the 3rd EU-Africa Summit in 2010, delegates of Africa and EU representatives had discussion on key issues that have direct relevance to African higher education. The issues included mobility, recognition of studies, capacity building, institutional leaderships and management, and quality assurance. The main messages of the declaration include the following: global challenges can be addressed through efficiently structured and sustainable HE partnerships; mobility within Africa should be reinforced and continually developed; sustainable 
information exchange and dialogue platform should be created to provide an umbrella for enhanced cooperation (EUA, 2010). In its reflection, on what Africa can learn from the Bologna Process, Association for the Development of Education in Africa (2011), noted that Africa shares with Europe many common drivers for educational reform (expansion, employability, globalization, skills shortage, etc.), but at the same time it was made clear that important differences also exist (demography, levels of academic infrastructure, local challenges, etc.). So, while Africa can learn from the European experience, it should not simply adopt the Process in creating its $\mathrm{HE}$ and research space, but rather adapt the approaches used to fit the African context, taking into account the uniqueness of indigenous African cultures and values (Association for the Development of Education in Africa, 2011).

African HE discussions have also been inspired by the focus within the Process on public responsibility for $\mathrm{HE}$ and more by the increasing attention given to the social dimension. This framework has enabled European and African HEIs to undertake a number of joint projects, focusing on issues such as equity and access to HE (EUA, 2010). To this end, one transformation initiative which links institutional, national, regional, continental and international endeavors is the African HE Harmonization and Tuning Project (Tuning Africa), which is part of the Africa-EU strategic partnership. This uses an internationally established methodology to enhance degree comparability, graduate mobility and employability (Tuning Africa, 2014). For instance, a good example is the Tuning Africa project which has been influenced by the Tuning Educational Structures in Europe project aiming at harmonizing curricula. Among the efforts include harmonization of curricula at different regions: Medicine (Northern Africa), Teacher education (Sothern Africa), Agriculture (Western Africa) and Mechanical engineering (Central Africa). In addition to such efforts, progress has been made by Francophone African countries, which are implementing reforms to align their systems with Europe's BP LMD system (a bachelor degree after three years, a masters after five and a doctorate after eight) (MacGregor, 2011). Individual countries are also trying to widen the scope of influence of the Bologna Process in addition to the efforts made by African countries themselves, EU and AU. For instance, France, among other countries, expressed a wish to see former colonies adapt to the Bologna Process. This adaptation is under way through various agreements (bilateral or multilateral cooperation) (Sall \& Ndjaye, 2008).

On the other hand, some African countries are also implementing part of the reform process though not clearly indicated in their policy documents that it is the Bologna Process's influence. Hence, it is possible to say that African HE is getting influenced by the Bologna Process supported by mega institutions, individual countries themselves and concerned associations. For instance, Ethiopia could be good example among other countries in Africa in implementing some of the elements of the Process. All public universities in Ethiopia are currently implementing Competence Based Education (CBE) curricula that affected the whole design of academic programs (modularization), assessment of students, and allocation of credits (ECTS) that has brought about a shift in thinking about students' and teachers' workloads. Let us see, in more detail, how the Process is reflected in Ethiopian HE taking some elements as basis for reflection.

\section{Influence of Bologna Process on Ethiopian Higher Education}

Needless to mention, globally, the HE sector has experienced "a surge in growth in this century, and its expansion has become a global phenomenon encompassing countries in all regions including those in Africa due to its increasing recognition for economic and social value" (Varghese, 2013). Similar experience was seen in expansion of HE in Ethiopia in the last two decades. Since the present government of Federal Democratic Republic of Ethiopia took power in 1991, both public and private HEIs have drastically increased in number. Though Ethiopian HE is relatively young that only started 60 years ago and with only one university before 20 years, there are currently 32 public universities. In addition, private provision of $\mathrm{HE}$ and training in Ethiopia started in early 2000 and now there are more than hundred such institutions in the country (Ministry of Education, 2013). In the last two decades, huge reform agenda were introduced into HE at both system and institution levels. A new education and training policy that has set out direction to changes in education system came to effect in 1994. Higher education Proclamations were envisaged in 2003 (No. 351/2003) and later revised 
Influence of the Bologna Process on African higher education: Ethiopian higher education in focus

in 2009 (No. 650/2009) that paved ways for the expansion and governance changes. As part of the reform process in the Ethiopian higher education, public universities are undergoing massive reform in their structure and function. Among these reform processes, curriculum reform process has got a major attention from the government (MoE and Higher Education Strategy Center) and universities in general. After universities introduced Business Process Re-engineering (BPR) as a change tool, many new elements have been introduced to the HE system. In this paper, as mentioned above, it is argued that the Bologna Process has influenced the system. To show this, ECTS, CBE and modularization, flexible learning path, recognition and mobility were selected from the basic elements of the Process. The elements are presented hereunder substantiated with evidence from experience and literature.

\subsection{The European Credit Transfer and Accumulation System (ECTS) and learning outcomes}

On the structural level, the Bologna Process has led to greater convergence in the architecture of national HE systems. The overall broadness of the guidelines expressed in communiqués and related texts, however, allows countries and institutions to maintain specific characteristics for most programs (Crosier \& Parveva, 2013). Two long-established elements of the 'Bologna toolkit' are the ECTS and the Diploma Supplement. ECTS was developed in the late 1980s, prior to the launch of the Bologna Process, to facilitate credit transfer in the Erasmus program and thus to foster student mobility. Over the decade since the year 2000, it has become a cornerstone of the implementation of the Bologna reforms. ECTS plays now an important part in curriculum design and in validating a range of learning achievements (academic or not). In this system, credits reflect the total workload required to achieve the objectives of program-objectives which are specified in terms of the learning outcomes and competences to be acquired-and not just through lecture hours. It makes study programs easy to read and compare for all students, local and foreign, and therefore facilitates mobility and academic recognition (EUA, 2010). Proper implementation of ECTS is one of the essential tools for reaching the Bologna goals. The use of ECTS for accumulation not only makes programs more transparent and supports the use of learning outcomes earned at another institution at home or abroad, but also those earned outside the formal education system (Crosier \& Parveva, 2013).

This key element of the Process is then directly practiced by Ethiopian universities. In the earlier times (before four years), prior to introduction of ECTS in Ethiopia, universities were using the traditional credit system that was expressed in terms of teachers' load. Previously, this system did not say anything about students' workload. However, with the use of ECTS, which is termed as EtCTS (Ethiopian Credit Transfer and Accumulation System) (HESC, 2013), many practices have been changed. For instance, the semester load of students was changed to 30 ECTS and the total ECTS load for different degree levels was also made to fit with the suggestion of ECTS user guide developed by the European Communities in 2009. This use of ECTS by all Ethiopian public universities is a good reflection of the Bologna's influence that changed the thinking of workload from teachers to students. For example, prior to the introduction of ECTS to the universities, the professors were not obliged to plan about how much time is needed for the student to accomplish an assignment or project and, if it happened, it was dependent on the willingness of the professor. In addition, the course outlines (known as course guidebooks or syllabus in some universities) did not show the module competencies for modules were introduced with the introduction of CB and ECTS.

Currently, it is common to see professor's indicating the module competencies, ECTS required to complete the course, the detailed activities required to achieve the competencies and the type and number of assessments to be used throughout the module which shows a clear influence of the Process. All curricula have been prepared in this way as there was harmonization of academic programs at national level. ECTS has also made the system of grading to be criterion-referenced which was norm-referenced and very transparent for students, professors, and other concerned bodies who are involved in monitoring the learning process. This is also indicated in the harmonized legislation of universities at national level (MoE, 2013). The important feature of ECTS which should be underscored and that can be seen as the success of the curriculum reform process, which also carries a great curricular meaning, is that ECTS considers the time students exert in their endeavors to learn the contents 
and thereby achieve the competencies outside classroom referred as 'home study'. Another feature of ECTS which has brought about a greater change is that it is founded on student-centered system. It is mainly based on the student workload required to achieve the objectives of a program, objectives preferably specified in terms of the learning outcomes and competences to be acquired.

In this regard, the role of ECTS in influencing the design process of academic programs was a key. This is because ECTS has shifted the thinking of workload from previously teacher centered to student centered way of calculation i.e., it has changed the haphazard use of student time to a measured time. As students' stay in universities is limited in time, arranging the academic programs in such a way seems logical. Therefore, this is one of the major influences of the Bologna Process in the reform process of Ethiopian HEIs.

\subsection{Competence Based Education (CBE) and Modularization}

One of the curricular reform components seen in the European Higher Education Area was aligning the existing curriculum or designing new academic programs with the ideals of CBE. This has brought about a shift in curriculum thinking as well- from traditional way of looking into curriculum as subject matter designed by professors within a university (subject matter) to designing it based on the need of the world of market. Here, it seems pertinent to explain the concept of CBE before showing how it is being reflected. Like other concepts in social sciences, there are also various definitions of $\mathrm{CBE}$ which have resulted in difficulty to easily conceptualize the concept. These variations seem exacerbated as defining CBE depends on how we define competence itself. Looking aside the various definitions as it has no importance to the purpose of this paper; many educators do agree that competence is the possession of certain attributes (knowledge, skills, and attitudes). For instance, Nasseh (1996) defined competence as state of having sufficient knowledge, judgment, and skill to carry responsibility and provide services.

On the other hand, Hall and Jones (1976, p. 29) defined competency as "a statement that describes the observable demonstration of a composite of the specific skills". Competence these days in general is encompassing not only skill (associated with vocational and technical education) but also knowledge and attitudes. In addition, competence includes applying what has been learnt in often different context. The thinking towards CBE, which lead to emphasizing the results of education rather than its processes, has brought a dramatic shift in what educators and policy-makers look for in judging the effectiveness of educational programs (Albanese et al., 2008) including in the EHEA and the rest of the world which are moving towards CBE. In this regard, the critical issue in $\mathrm{CBE}$ is that the learner reaches the specified level of performance in a competency and the educational process is secondary.

$\mathrm{CBE}$ is a framework for designing and implementing education that focuses on the desired performance characteristics of specific field professionals (Gruppen, Mangrulkar \& Kolars, 2012). In general, the move towards CBE means aligning academic programs in line with the capability of students to function effectively in the world of market. There are a number of national and international initiatives, and reasons including the post-industrial knowledge economy that urged the move towards CBE. Relating learning with the world of work becomes the economic trend of the day. The need for closer link between academic learning and professional practice is now higher than ever. Some of the reasons include: to increase transparency of professional profiles in study programs, to shift to a more learner oriented approach to education, and to develop higher levels of employability and shared language for consultation with all stakeholders. Though the reasons may vary depending on countries' context, CBE was one of goals of the Bologna Process (Voegtle, Knill, \& Dobbins, 2010).

The current Ethiopian universities' move towards CBE is characterized similarly by a move towards the market and increased involvement of stakeholders. As reflected in their BPR studies, which was taken as a basis for the curriculum reform process in Ethiopian universities, many of the universities in Ethiopia asserted that the academic programs delivered are characterized by: loose connection with the world of work, unmatched to 
Influence of the Bologna Process on African higher education: Ethiopian higher education in focus

stakeholders' needs and based on poor analysis of labor market demands and expected skills and knowledge, marginalized program outcomes in the organization of curricula and lack of continuous curriculum/program follow up and reviewing (MoE, 2012; Addis Ababa University, 2008; Bahir Dar University, 2010). In general, the need for CBE in Ethiopian HE was based on tangible gap of universities to address the need of market or employability of graduates. This attempt to relate with world of market makes to have a link with the Bologna Process of CBE.

The Bologna Process originates from the recognition that "in spite of their valuable difference, European HE systems are facing common internal and external challenges related to the growth and diversification of higher education, the employability of graduates, the shortage of skills in key areas and the expansion of private education" (EUA, 2010). In this regard, in the last five years Ethiopian universities have been doing their best to fit their existing curriculum into competence based curricula. The chosen model to convert the existing academic programs into modules that are based on competencies was clustering of courses or conversion model-categorizing courses to form modules based on their contribution to the competence (MoE, 2012). In addition to the introduction of CBE, HEIs in Ethiopia have embarked on major reform since last decade (MoE, 2012).

As mentioned earlier, for the reform to take effect, the institutions have used BPR as a tool. In the reengineering process, modularization was proposed as or as one of the ways for designing academic programs. According to the HESC guideline, there are a number of reasons why HEIs opted for modularization. The first one is that the existing curricula are discipline based and the courses are fragmented. They are not organized around competences. As a result, the curricula do not enable HEIs to produce competent graduates. The second reason, which is based on the concept of ECTS, is that the existing curriculum does not say anything about student workload which is very important for students' success in their academic life. In the previous practices, consideration was made for the contact hours that the instructor uses in the classroom. Hence, student workload is one of the central points in the modularization. The third is that there is a loose connection between the world of education and the world of work because of the inherent problem of the then existing curricula. According to HESC (2013), modularization is believed to increase degree comparability and compatibility, curriculum flexibility, and student mobility similar with the Bologna experience. Hence, the Bologna Process has its own direct and indirect influence on the HE system of Ethiopia in terms of CBE and modularization.

\subsection{Flexible Learning Paths, and Recognition and Mobility}

Other emerging elements of the Bologna Process in the EHEA are flexible learning paths, and recognition and mobility. Though it is very hard to directly trace how some of these vital reform processes are observed in the Ethiopian universities for mobility has transnational dimension, it is possible to indicate some changes in the delivery and assessment of instruction. In addition, while Ethiopian universities were in a move to harmonize their academic programs for the last two years, one of the reasons for harmonization was to enhance students' mobility across the universities in the country and worldwide.

Before citing examples to show how these elements are being practiced, it is useful to define what flexible learning path is in the European context. In the report by Ruth (2006, p. 15) submitted to the European Commission on the extent and impact of HE curricular reform across Europe, flexible learning paths is referred as:

... either an increase in the diversity of teaching modes; an increase of the number of entry and exit points; the permeability between vocational and higher education or between different parts of the higher education system, the promotion of excellence tracks, modularization and the validation of prior learning.

From this definition, it is possible to see that flexible learning path has many elements in it. Let us then focus on some of these elements reflected in Ethiopian universities practice after the introduction of ECTS, CBE 
and modularization. One of the major reforms still currently undergoing in Ethiopian universities is modularization. As indicated in the guideline for modularization prepared by HESC, the need for revising the existing courses offered in universities into modules based on the competences they are supposed to achieve was underlined (HESC, 2012). In this guideline, many countries in Europe such as the Netherlands, Germany and others were benchmarked for their provision of courses through modules.

The other element of flexible learning path is increase in the diversity of teaching modes and the validation of prior learning. Related to these elements, with the start of modular type of delivery and ECTS, the new national harmonized legislation has given attention for recognition of prior learning and assessment practices. For instance, to cite a specific case, in the previous legislation of Bahir Dar University (2005), one of the biggest universities in the country, students had no chance to take a requite course if they fail to score an average mark. But, in the new legislation, students can take any course as far as they fulfill the required attendance and assignments for the course. For instance, Article 18, Requisites, states "There are no requisites and pre-requisites of courses. A student who has obtained "F" grade in a course while fulfilling the required attendance shall be allowed to take the requisite course. .... However, if the requisite course needs prior knowledge of the previous course the academic advisor shall advise the student to withdraw but the decision to take or not rests up on the student" (Bahir Dar University, 2011, p. 2). Such measures show flexibility and recognition of prior learning of students on one hand and presence of self-contained modules on the other. After the adoption of ECTS, modularization and CBE, the assessment practice has also been changed significantly.

Prior to the introduction of these elements, assessment practice in Ethiopian universities was highly criticized for its lack of helping students' learning. For instance, the baseline studies conducted by Bahir Dar and Hawassa Universities to introduce BPR into their system have shown problems of assessment practice. Among the problems reported include: time bounded student learning assessment (mid and end of the semester), assessment is provided as something different from learning, cheating, temporal learning for a week, teaching for helping students pass exam, repetition of exam papers and students hunting exam papers, and focus on lower educational outcomes (Bahir Dar University, 2009). Though all these problems have not yet been solved, there is significant improvement after the movement towards the elements mentioned. For instance, assessment has become continuous and was legislated. All professors or lecturers in general are required to prepare detailed course plans and need to show the types, number of assessments and active learning methodologies to be used in their modules. In this regard, the Bologna Process elements and experience of European universities have played a major role. With regard to mobility, the harmonization process going on by Ethiopian public universities might ease the mobility of students within the country. All academic programs except medicine in all public universities are undergoing harmonization at national level and this will have a major contribution for mobility inside and outside the country. Here, it should be noted that the current harmonization process is the result of introduction of $\mathrm{CBE}$ and modularization into the system of Ethiopian HE despite previous attempts to harmonize the earlier curricula at national level on selected disciplines.

\section{Opportunities and Challenges of Implementing the Bologna Process}

Africa's HEIs have an opportunity to learn from the Bologna Process. For instance, before Bologna, European HEIs were facing the challenges of disparate HE systems, insufficient academic mobility, diverse providers, a multitude of languages and non-uniformity in quality provision. However, after the introduction of Bologna followed by subsequent follow-ups and meetings, targeting to creating a Europe of knowledge that is globally competitive laid down the foundations for creating a EHEA in which universities would play a central role (EUA, 2010). Currently, the Process has enabled Europe to have the EHEA. Hence, African HE has a huge opportunity to learn from the process itself. Particularly, a well-planned systemic approach supported by ministers, forming groups that regularly follow up such process and strong involvement of all stakeholders are some of the relevant lessons Africa can learn from Europe. In addition, the Process has made it easier for countries, organizations and HEIs outside Europe to cooperate with their counterparts in Europe, and vice versa. Among these gains include: transparency of degree structures, mobility within Europe, visibility of the quality of 
Influence of the Bologna Process on African higher education: Ethiopian higher education in focus

European HEIs and their students, the possibility of setting up joint degrees, the added value of European HEIs to educate intercultural citizens that are aware of societal needs, all contribute to the attractiveness of the EHEA and of its HEIs (Bologna Follow-up Group, 2009). Hence, if Africa could work hard towards achieving the good lessons and if AU and Association of African Universities could materialize their partnerships with EU and EUA, Africa could benefit from these gains despite expected challenges for its HE is diversified (mainly attributed to the variations of systems of education of earlier colonial powers) and facing incapacity problems. For instance, the introduction of Credit System at "continental level has benefits of connecting African higher education with the global higher education system, and lessening the challenges and risks of internationalization of higher education" (Adamu, 2012, p. 208).

On the other hand, Ethiopian HE system has got an opportunity to introduce elements of the Bologna Process such as the ECTS that has brought about a shift in thinking and practice in the teaching and learning process. In addition, taking the good practices so far achieved on areas such as ECTS and CBE, addition of other elements for instance use of diploma supplement and qualification framework should also be considered. In fact, currently, the Ethiopian ministry of education in collaboration with relevant stakeholders is preparing National Qualification Framework, which it never had before. Among the frameworks possibly referred to was the European Qualification Framework, a tool that has been introduced and developed in the Bologna Process. This framework has got wider scope and service as a mechanism to monitor quality in Europe. It is then worth mentioning that the development of the qualification framework in Ethiopia could get an opportunity to learn from such standards and guidelines. Though the clear influence of such frameworks might be seen after the launch of the Ethiopian Qualification Framework, it is noteworthy to indicate at this moment that referring such well-established frameworks will have much help in developing one's own framework. This then could be taken as a major contribution of the Bologna Process to other countries. It is because, even in Europe prior to the Bologna Process, only a handful of countries had established clear external quality assurance systems (Crosier \& Parveva, 2013).

Though the key issues of the Process will continue to have a direct relevance to the rest of the world as shown above taking the good practices so far achieved on areas such as recognition of diplomas and degrees, and quality assurance (Crosier \& Parveva, 2013), the Process will also have its own challenges to get implemented by African countries such as Ethiopia. The challenges include contextual differences in terms of academic culture, institutional arrangement, involvement of stakeholders and implementation capacity among others. For instance, all the elements discussed above are being implemented only in public HEIs (universities funded by the government). Private HEIs are following none of the above mentioned elements and it would be very challenging for the country in the future to address the issue. For instance, students completing with same nomenclature (for example bachelor degree in management) from public and private institutions means different things to employers. First, the public HEIs are offering degree based on competence following the recent reforms in modularization while the private institutions are following the traditional curricula. Secondly, the public institutions are implementing ECTS whereas the private colleges and universities are still following the traditional teacher centered credit based system. Hence, if such gaps are to continue unaddressed, it may create a huge challenge to the system at all. Thirdly, nationally established institutions such as the Higher Education Relevance and Quality Agency (HERQA) whose mandate is to monitor the quality of education in HE may face challenges of setting general standards and procedures for both public and private HEIs as they are practicing differently organized curricula and process. In general, despite the Bologna has succeed in brining Europe into comparable often convergent HE system in some elements, there seems much work ahead for Ethiopian as well as African HE to have comparable and readable degrees.

\section{Conclusion}

In this paper, attempt was made to show how Bologna has influenced directly or indirectly the Ethiopian HE system. Mention was also made to see the endeavors Africa has made so far to adapt the Bologna Process despite the existence of limited literature in the area. Some of the elements of the Process were taken as basis to show 
how they are reflected in Ethiopian HE. In this regard, the elements ECTS, CBE and modularization, flexible learning paths, and recognition were discussed. Particularly, the first three elements and flexible learning paths in terms of application of diverse learning methods were clearly pointed out. In addition, the opportunities and challenges so far observed were discussed. Among the lessons worth considering in future activities is stakeholders' involvement in decision-making procedures which is one of the major strengths of the Bologna Process's experience in Europe. It is also a crucial factor for success in the implementation of the Bologna Process reforms at national contexts. In this regard, as Ethiopian universities are moving towards competence based curriculum, taking this lesson will have a major importance for the success of their reform. The AU could also take lesson from the EU as the later is very active on issues of HEIs. The recent joint agreements made between EU and AU should be strengthened. It is vivid to see how the EU is acting beyond political institution in supporting reform process of HE. AU should support and strengthen the HE reform process, and the partnerships so far made with EUA and EU should be translated into practice. It is possible to say at this point in time that it is high time for African HEIs to take actions as soon as possible as they may suffer from isolation and lack of comparability of degrees that may significantly affect students' mobility.

As some authors have asserted, without the combination of the political commitment of governments, the active engagement of the European Commission, and the strong role of university associations and student union, it would not have been possible for the Bologna Process to achieve the gains so far achieved. Involvement of stakeholders, which apparently looks weaker in Africa, at national, regional and continental level should be boosted if African HE is to compete at global arena. Despite these positive lessons, the Bologna Process, however, is not free of criticism for it's over emphasis on conformity, convergence and harmonization at continental level. For instance, Palfreyman (2008) criticized the Process for its attempt of creating a system of HE in Europe citing USA's success in HE without having a system. Yet, this author asserted that the Bologna Process has moderately achieved structural reforms within resistant and inefficient national HE systems to save taxpayers' money (Palfreyman, 2008). Hence, African or Ethiopian HE can get relevant lessons from practicing the elements of Bologna Process. For instance, ECTS, flexibly learning paths, recognition of studies can be taken as good lessons from the Process. Harmonization, convergence than sameness, of academic curricula and deployment of quality assurance procedures would also be relevant to have more comparable and flexible systems for students and staff mobility. Finally, the Process should serve African and other countries which are in the process to adapt it as an example than adopting and implementing it as it is as the contexts are different among countries and HE systems.

\section{References:}

Adamu, A.Y. (2012). Internationalization of higher education in Africa: Introducing credit accumulation and transfer system. International Journal of Public Policy, 8(4/5/6), 199-213. http://dx.doi.org/10.1504/IJPP.2012.048713

Addis Ababa University. (2008). Teaching and learning in graduate programs at AAU-report on the current (AS-IS) situation. Addis Ababa.

Albanese, M.A., Mejicano, G., Mullan, P., Kokotailo, P., \& Gruppen, L. (2008). Defining characteristics of educational competencies. Medical Education, 42, 248-255.

Association for the Development of Education in Africa. (2011). Working Group on Higher Education, creating an African higher education and research Space. Retrieved 05 February 2014 https://sig.ias.edu/news/adea-creating-african-higher-education-and-research-space

Bahir Dar University. (2009). Business Process Reengineering-t-Learning redesign compendium-detailed design, unpublished research, Bahir Dar.

Bahir Dar University. (2011). Academic regulation for modular curricula, approved by the Senate of Bahir Dar University. Bahir Dar.

Bologna Follow-up Group. (2009). The European Higher Education Area (EHEA) in a global context: Report on overall developments at the European, national and institutional levels, Approved by BFUG at its 
Influence of the Bologna Process on African higher education: Ethiopian higher education in focus meeting in Prague, 12-13 February 2009, Retrieved 06 February 2014 from http://www.ondvlaanderen.be/hogeronderwijs/bologna/conference/documents/2009_EHEA_in_global_ context.pdf

Crosier, D., \& Parveva, T. (2013). The Bologna Process: Its impact in Europe and beyond. UNESCO: International Institute for Educational Planning. Paris. Retrieved January 5, 2014 from http://unesdoc.unesco.org/images/0022/002206/220649e.pdf

Education, Audiovisual and Culture Executive Agency. (2012). The European Higher Education Area in 2012: Bologna Process Implementation Report. Retrieved February 10, 2014 from Retrieved on May 15, 2013 http://www.ehea.info/Uploads(1)/Bologna\%20Process\%20Implementation\%20Report.pdf

European Commission (Education and Training). (2013). European Credit Transfer and Accumulation System. (ECTS) http://ec.europa.eu/education/lifelong-learning-policy/ects_en.htm

European Communities. (2009). ECTS Users' Guide. Retrieved on May 10, 2012 from http://ec.europa.eu/education/lifelong-learning-policy/doc/ects/guide_en.pdf

European higher education area. (2014). 'The Bologna Process 2020: The European higher education area in the new decade'. Communiqué. Conference of European Ministers Responsible for Higher Education, Leuven and Louvain-la-Neuve, Belgium, 28-29 April 2009. Retrieved 07 February 2014 from http://www.ehea.info/Uploads/Declarations/Leuven_Louvain-la-Neuve_Communiqu\% C3\%A9_April_ 2009.pdf

European Universities Association. (2010). Conference report: Supporting academic mobility and the revitalization of higher education in Africa (Side Event of the 3rd EU-Africa Summit) Retrieved 07 February 2014 from http://www.eua.be/News/10-11-25/Conference_report_Supporting_academic_mobility_and_the_revitali sation_of_higher_education_in_Africa_Side_Event_of_the_3rd_EU-Africa_Summit.aspx

European Universities Association. (2010).Europe's New Higher Education Landscape, retrieved on January 25, 2014 from http://www.eua.be/fileadmin/user_upload/files/publications /EUA_Bologna_brochure nov06_v2l.pdf

Federal Democratic Republic of Ethiopia. (2003). Federal Negarit Gazeta of the Federal Democratic Republic of Ethiopia 15th Year, No. 64 Addis Ababa 17th September, 2003 Higher Education Proclamation No. $72 / 2003$.

Federal Democratic Republic of Ethiopia. (2009). Federal Negarit Gazeta of the Federal Democratic Republic of Ethiopia 15th Year, No. 64 Addis Ababa 17th September, 2009 Higher Education Proclamation No. 650/2009.

Gruppen, L.D., Mangrulkar, R.S., \& Kolars, J.C. (2012). The promise of competency-based education in the health professions for improving global health. Human Resources for Health, 10:43. Retrieved February 6, 2014 from http://www.human-resources-health.com/content/10/1/43

Hall, G., \& Jones, H. (1976). Competency-based Education: A process for the improvement of education. Englewood Cliffs, NJ: Prentice-Hall.

Karseth, B. (2006). Curriculum restructuring in higher education after the Bologna Process: A new pedagogic regime? Revista Española de Educación Comparada, 12, 255-284, retrieved on January 25, 2014 from http://www.uned.es/reec/pdfs/12-2006/10_karseth.pdf

Knight, J. (2003). Updating the definition of internationalization. International Higher Education. Fall, number 33, retrieved February 5, 2014 from http://www.bc.edu/content/dam/files/research_sites/cihe/pdf/IHE pdfs/ihe33.pdf

Knight, J. (2003). Updating the Definition of Internationalization. International Higher Education. Fall, number 33. Retrieved February 5, 2014 from http://www.bc.edu/content/dam/files/research_sites/cihe /pdf/IHEpdfs/ihe33.pdf

MacGregor, K. (2011). ‘Africa: Higher education space gaining momentum'. In: University World News, Africa Edition, No. 79, 5 June.

Ministry of Education. (2011/12). Education statistics annual abstract: 2004 E.C. /2011-2012 G.C. Addis Ababa: Ministry of Education. 
Gebremeskel, H. H.

Ministry of Education. (2012). A Guideline for modularization to Ethiopian higher education institutions, Organized by Higher Education Strategy Center (HESC), Addis Ababa, Ethiopia

Ministry of Education. (2013). Harmonized academic policy of Ethiopian public higher education institutions. Addis Ababa.

Palfreyman, D. (2008). The legal impact of Bologna implementation: exploring criticisms and critiques of the Bologna process. Education and the Law, 20(3), 249-257. http://dx.doi.org/10.1080/09539960903003974

Roger Y., \& Chao, Jr. (2011): Reflections on the Bologna Process: the making of an Asia Pacific Higher Education Area. European Journal of Higher Education, 1(2-3), 102-118. http://dx.doi.org/10.1080/21568235.2011.629040

Ruth, K. (2006).The Bologna Process and the Lisbon research agenda: The European Commission's expanding role in higher education discourse. European Journal of Education, 41(2). Retrieved on January 23, 2014 from http://www.utwente.nl/mb/cheps/summer_school/literature/keeling\%20eje.pdf

Sall. H. N., \& Ndjaye, B. D. (2008). Higher education in Africa: Between perspectives opened by the Bologna Process and the Commodification of Education. European Education, 39(4), 43-57. http://dx.doi.org/10.2753/EUE1056-4934390403

Sewonu, R. (2010). Bologna Process and its impact on African higher education. Triennial Africa Conference, October 4-8, 2010.

Shahjahan, R. A. (2012). The roles of international organizations (IOs) in globalizing higher education policy. In J. C. Smart, M. B. Paulsen (eds.), Higher Education: Handbook of Theory and Research, Higher Education: Handbook of Theory and Research, Media B.V. http://dx.doi.org/10.1007/978-94-007-2950-6_8

Sweeney, S. (2010).Bologna Process: Responding to the post-2010 challenge. Retrieved on February 01, 2014 from http://www.britishcouncil.org/bolognaprocess_final.pdf

Taylor, J., Hanlon, M. \& Yorke, M. (2013). The evolution and practice of institutional research. New Directions for Institutional Research, 2013(15), 59-75. http://dx.doi.org/10.1002/ir.20039

Varghese, N.V. (2013). Governance reforms in higher education: A study of selected countries in Africa International Institute for Educational Planning, UNESCO. Retrieved on February 01, 2014 from http://www.iiep.unesco.org/fileadmin/user_upload/News_And_Events/pdf/2013/ Governance reforms_in_HE_paper_PF.pdf

Voegtle, E. M., Knill, C. \& Dobbins, M. (2011). To what extent does transnational communication drive cross-national policy convergence? The impact of the bologna-process on domestic higher education policies. Higher Education, 6(1), 77-94. http://dx.doi.org/10.1007/s10734-010-9326-6

Zgaga, P. (2006). Looking out: The Bologna Process in a global setting, on the "External Dimension" of the Bologna Process, Norwegian Ministry of Education and Research. Retrieved February 02, 2014 from http://www.ehea.info/Uploads/Global\%20context/Bologna_Process_in_global_setting_finalreport.pdf 